\title{
Phosphorescent Oxygen Sensor with Dendritic Protection and Two-Photon Absorbing Antenna
}

\section{SUPPORTING INFORMATION}

\author{
Raymond P. Briñas, ${ }^{1}$ Thomas Troxler, ${ }^{2}$ Robin M. Hochstrasser ${ }^{2}$ and Sergei A. Vinogradov ${ }^{1 *}$ \\ Departments of Biochemistry and Biophysics ${ }^{1}$ and Chemistry ${ }^{2}$, University of Pennsylvania, \\ Philadelphia, PA 19104
}

E-mail: vinograd@mail.med.upenn.edu

\section{Materials and Methods}

All solvents and reagents were obtained from commercial sources and used as received. Tetramethoxycarbonylphenylporphyrin $\left(\mathrm{H}_{2} \mathrm{TMCPP}\right)$ was synthesized as described for previously. ${ }^{1} \mathrm{Pt}$ was inserted into $\mathrm{H}_{2} \mathrm{TMCPP}$ using $\mathrm{PtCl}_{2}$ in refluxing benzonitrile under $\mathrm{Ar}$ atmosphere (see Supporting Information). Pt octabutoxycarbonylporphyrin (PtOBCPP) and $\mathrm{Pt}$ octacarboxphenylporphyrin (PtOCPP) were synthesized as described previously. ${ }^{2}$ Newkome-type dendron 9 was synthesized according to Cardona and Cawley. ${ }^{3}$ Synthesis of CBz-protected arylglycine $\mathbf{1 0}$ followed the published procedure. ${ }^{4}$ Reactions were monitored by thin-layer chromatography using pre-coated TLC plates. Column chromatography was performed on Selecto ${ }^{\mathrm{TM}}$ silica gel (Fisher). Preparative GPC was performed on S-X1 (Biorad) beads, using THF as a mobile phase. ${ }^{1} \mathrm{H}$ and ${ }^{13} \mathrm{C}$ NMR spectra were recorded on a Varian Unity $500 \mathrm{MHz}$ spectrometer at ambient temperatures, unless otherwise stated. The mass spectra were obtained on a MALDI-TOF Voyager$\mathrm{DE}^{\mathrm{TM}} \mathrm{RP}$ BioSpectrometry workstation, using $\alpha$-cyano-4-hydroxycinnamic acid as the matrix, unless otherwise stated. Analytical GPC (SEC) was performed on a Perkin-Elmer Series 10 high pressure liquid chromatograph, equipped with an LC-100 column oven and two Perkin-Elmer PL gel columns. Synthetic details and the analytical data for all the compounds described in this paper are given in the Supporting Information. 
Quartz fluorometric cells (Starna, Inc, $1 \mathrm{~cm}$ optical path length) were used in both linear and non-linear optical experiments. Linear optical spectra were recorded on a Perkin-Elmer Lambda 35 UV-Vis spectrophotometer and the steady state fluorescence and phosphorescence measurements were performed on a SPEX Fluorolog-2 spectrofluorometer (Jobin-Yvon Horiba), equipped with an infrared enhanced R2658P PMT (Hamamatsu, Inc.). Emission spectra were obtained using solutions with absorption at the excitation maxima of about 0.02 OD. Quantum yields of emission of all the dyes were measured relative to the fluorescence of tetraphenylporphyrin $\left(\phi_{\mathrm{f}}=0.11 \text { in } \mathrm{C}_{6} \mathrm{H}_{6}\right)^{5}$ or anthracene $\left(\phi_{\mathrm{f}}=0.3\right.$ in $\left.\mathrm{EtOH}\right){ }^{6}$

Time resolved phosphorescence measurements were performed using an in house constructed time-domain phosphorometer. A close analog of this instrument was described elsewhere. ${ }^{7}$ In brief, the excitation sources in the phosphorometer are LED's (10 mW, Hewlett-Packard) and the detector is an APD (Hamamatsu, $3 \mu$ s rise time). The instrument is based on a 16-bit PCI-5062E board (National Instruments, Inc.), $333 \mathrm{kHz}$ clock frequency. For phosphorescence measurements, the solutions were deoxygenated by Ar bubbling as the phosphorescence lifetimes were continuously monitored, and the cells were sealed when the lifetimes became constant. Aqueous solutions were deoxygenated using an enzymatic system (glucose/glucose oxidase/catalase). ${ }^{8}$ The steady state emission measurements were performed immediately after sealing the cuvettes. A previously described setup ${ }^{9}$ was used to determine the phosphorescence oxygen quenching constants, except that a time-domain instead of a frequency-domain phosphorometer was used for lifetime measurements.

An amplified mode locked Ti:Sapphire laser system (Clark-MXR) $\left(\lambda_{\max }=780 \mathrm{~nm}\right.$, pulse width $110 \mathrm{fs}, 100 \mu \mathrm{J}$ per pulse, $1 \mathrm{kHz}$ repetition rate, i.e. about $5 \times 10^{28}$ photons $\mathrm{cm}^{-2} \mathrm{~s}^{-1}$ during the pulse) was used as the excitation source in non-linear optical experiments. A beam from the laser was passed through a half wave plate and a polarizing cube, so that the excitation power could be tuned continuously by rotating the wave plate, and directed into the sample cell with a typical beam diameter of $3 \mathrm{~mm}$. The power of the excitation beam after attenuation was measured using an optical power meter (Coherent). The emission spectra were recorded in a right angle setup, using a liquid nitrogen cooled CCD camera (Princeton Instruments) connected to a monochromator (Acton Research). The solutions used for $2 \mathrm{P}$ phosphorescence measurements were typically characterized by about 1 OD absorption at the Pt porphyrin Q-band maxima $(510 \mathrm{~nm})$. The spectra were acquired during 20-30 s integration time periods. All emission spectra obtained using $2 \mathrm{P}$ excitation are reported uncorrected for the detector response.

2PA cross-sections of the fluorescent (coumarins) and phosphorescent (Pt porphyrin) dyes were determined by the relative fluorescence method, ${ }^{10}$ using Rhodamine $\mathrm{B}$ in $\mathrm{MeOH}$ as a standard $\left(\sigma_{2}=200\right.$ 
GM in EtOH). ${ }^{11}$ The extinction coefficients of the dyes and their emission quantum yields were obtained from the literature or determined in independent linear experiments (see above).

In time resolved 2P phosphorescence measurements, the collection light guide of the time domain phosphorometer was positioned at right angle to the excitation beam of the laser, about 1-2 $\mathrm{mm}$ from the cell. The detection sequence of the phosphorometer was synchronized with the laser, so that the acquisition was initiated after a 10-20 $\mu$ s delay following the excitation pulse. About 5001000 scans were averaged in a typical run to obtain a phosphorescent trace with adequate signal-tonoise ratio. The decay was fitted to a single exponential to give the phosphorescence lifetime $(\tau)$ and the initial intensity $\left(\mathrm{I}_{0}\right)$. The integral intensity of the decay was calculated as the product $\tau \times \mathrm{I}_{0}$ and normalized by the sample concentration. The latter was assumed to be proportional to the value of the absorbance at the Q-band maximum (510 nm).

\section{Synthesis}

PtTMCPP. To a refluxing mixture of meso-tetrakis(4-methoxycarbonylphenyl)porphyrin (724 $\mathrm{mg}, 0.854 \mathrm{mmol})$ in benzonitrile $(100 \mathrm{~mL}) \mathrm{PtCl}_{2}(273 \mathrm{mg}, 1.03 \mathrm{mmol})$ was added under $\mathrm{Ar}$ atmosphere. The resulting mixture was refluxed for about $7 \mathrm{~h}$, and the reaction was stopped when the fluorescence of the free-base porphyrin $\left(\lambda_{\max }=645 \mathrm{~nm}\right)$ disappeared. After the removal of benzonitrile, the residue was purified by column chromatography (silica gel, $2 \%$ THF in $\mathrm{CH}_{2} \mathrm{Cl}_{2}$, followed by $5 \%$ THF in $\mathrm{CH}_{2} \mathrm{Cl}_{2}$ ). The crude product was recrystallized from $\mathrm{CH}_{2} \mathrm{Cl}_{2} / \mathrm{MeOH}$ to afford dark red-purple crystals of PtTMCPP. Yield: $476 \mathrm{mg}, 53.6 \%$; ${ }^{1} \mathrm{H}$ NMR $\left(\mathrm{CDCl}_{3}, \delta\right): 8.72$ (s, 8H), 8.42 (d, J = 8.5 Hz, $8 \mathrm{H}), 8.22(\mathrm{~d}, \mathrm{~J}=8.5 \mathrm{~Hz}, 8 \mathrm{H}), 4.10(\mathrm{~s}, 12 \mathrm{H}) ;{ }^{13} \mathrm{C} \mathrm{NMR}\left(\mathrm{CDCl}_{3}, \delta\right): 167.4,146.0,140.7,134.1,131.1$, 130.2, 128.3, 121.8, 52.6; UV-Vis $\left(\mathrm{CH}_{2} \mathrm{Cl}_{2}\right) \lambda_{\max }(\log \varepsilon): 403$ (5.40), 509 (4.41), 539 (3.77) nm; MALDI-TOF $(\mathrm{m} / \mathrm{z})$ : calcd for $\mathrm{C}_{52} \mathrm{H}_{36} \mathrm{~N}_{4} \mathrm{O}_{8} \mathrm{Pt}: 1039.22$, found: $1040.58\left[\mathrm{M}^{+}\right]$.

PtTCPP. Four-five KOH pellets were added to a well-stirred mixture of PtTMCPP (183 mg, $0.176 \mathrm{mmol})$ in $1 \% \mathrm{EtOH}$ solution in THF $(100 \mathrm{~mL})$. The mixture was stirred at r.t. for $3 \mathrm{~h}$, after which the mixture was concentrated, and several drops of water were added to dissolve the precipitate formed. The solution was stirred for $1 \mathrm{~h}$ and then THF was removed by rotary evaporation. The mixture was filtered and acidified with conc. $\mathrm{HCl}$. The precipitate was isolated by centrifugation and washed with water three times to give pure PtTCPP as dark red-purple solid. Yield: $155 \mathrm{mg}, 89.6 \%$; 
${ }^{1} \mathrm{H}$ NMR (DMSO-d $\left.d_{6}, \delta\right): 13.29$ (br s, 4H), 8.73 (s, 8H), 8.35 (d, $\left.J=7.5 \mathrm{~Hz}, 8 \mathrm{H}\right), 8.26(\mathrm{~d}, J=7.5 \mathrm{~Hz}$, $8 \mathrm{H}) ;{ }^{13} \mathrm{C}$ NMR (DMSO- $\left.d_{6}, \delta\right): 167.3,144.5,139.8,133.9,131.2,130.7,128.0,121.6$.

N-Boc protected EDA-coumarin adducts 1 and 2 (general procedure). A coumarin compound (0.526 mmol) and 2-chloro-4,6-dimethoxytriazine (CDMT) (91 mg, $0.518 \mathrm{mmol})$ were dissolved in acetonitrile $(30 \mathrm{ml})$. After cooling the mixture to $0^{\circ} \mathrm{C}, \mathrm{N}$-methylmorpholine (NMM) (53 $\mathrm{mg}, 0.526$ mmol) was slowly added. The resulting mixture was stirred at $0^{\circ} \mathrm{C}$ for $2 \mathrm{~h}$, and a solution of $\mathrm{N}-(2-$ aminoethyl)carbamic acid tert-butyl ester ( $83 \mathrm{mg}, 0.520 \mathrm{mmol})$ and NMM (53 $\mathrm{mg}, 0.526 \mathrm{mmol})$ in acetonitrile $(10 \mathrm{ml})$ was added. The mixture was stirred at $0^{\circ} \mathrm{C}$ for another $2 \mathrm{~h}$ and then at r.t. for $12 \mathrm{~h}$. The solvent was evaporated in vacuum, and the residue was dissolved in $\mathrm{CH}_{2} \mathrm{Cl}_{2}$. The organic mixture was washed successively with water, $10 \%$ citric acid, water, saturated solution of aq. $\mathrm{NaHCO}_{3}$ and water and dried over $\mathrm{Na}_{2} \mathrm{SO}_{4}$. After the removal of solvent in vacuum, the crude product was purified either by recrystallization or precipitation from an appropriate solvent.

CCA-EDA-Boc (1). Recrystallization from EtOAc/petroleum ether afforded $\mathbf{1}$ as white needles. Yield: $127 \mathrm{mg}, 74 \%$. UV-Vis $\left(\mathrm{CH}_{2} \mathrm{Cl}_{2}\right) \lambda_{\max }(\log \varepsilon): 294(4.12), 333(3.91) \mathrm{nm} .{ }^{1} \mathrm{H}$ and ${ }^{13} \mathrm{C} \mathrm{NMR}$ and MALDI-TOF spectra are in agreement with the previously reported data. ${ }^{12}$

C343-EDA-Boc (2). The product was purified by re-precipitation from $\mathrm{CH}_{2} \mathrm{Cl}_{2}$ upon addition of by petroleum ether. Yield: $124 \mathrm{mg}, 83 \% .{ }^{1} \mathrm{H} \mathrm{NMR}\left(\mathrm{CDCl}_{3}, \delta\right): 9.00$ (br s, $\left.1 \mathrm{H}\right), 8.58(\mathrm{~s}, 1 \mathrm{H}), 6.99$ (s, $1 \mathrm{H}), 3.56(\mathrm{q}, J=5.8 \mathrm{~Hz}, 2 \mathrm{H}), 3.33(\mathrm{~m}, 6 \mathrm{H}), 2.88(\mathrm{t}, J=6.5 \mathrm{~Hz}, 2 \mathrm{H}), 2.76(\mathrm{t}, J=6 \mathrm{~Hz}, 2 \mathrm{H}), 1.97(\mathrm{~m}$, $4 \mathrm{H}), 1.43(\mathrm{~s}, 9 \mathrm{H}) ;{ }^{13} \mathrm{C} \mathrm{NMR}\left(\mathrm{CDCl}_{3}, \delta\right): 164.7,163.2,156.3,152.9,148.5,148.4,127.3,119.9,108.9$, 108.5, 105.9, 79.4, 50.47, 50.1, 41.3, 39.8, 28.6, 27.7, 21.4, 20.4, 20.3; UV-Vis $\left(\mathrm{CH}_{2} \mathrm{Cl}_{2}\right) \lambda_{\max }(\log \varepsilon)$ : 435 (4.58); MALDI-TOF (m/z): calcd for $\mathrm{C}_{23} \mathrm{H}_{29} \mathrm{~N}_{3} \mathrm{O}_{5}$ : 427.21 ; found: 425.89 [M $\left.{ }^{+}\right]$.

Coumarin-EDA adducts $1 \mathrm{a}$ and $2 \mathrm{a}$ (general procedure). ${ }^{12}$ Coumarin-EDA-Boc $(0.16 \mathrm{mmol})$ was dissolved in cold TFA $(1 \mathrm{~mL})$. The resulting solution was stirred at r.t. for $2-3 \mathrm{~h}$. The excess TFA was removed in vacuum. The residue was mixed with an ample amount of $\mathrm{CH}_{2} \mathrm{Cl}_{2}$ to form a solution, and the solvent was removed in vacuum again. This process was repeated several times to remove the residual TFA. The remaining solid was suspended in $\mathrm{CH}_{2} \mathrm{Cl}_{2}$ and the mixture was centrifuged to obtain a pure product, as a TFA-salt.

CCA-EDA (1a). Yield: $43 \mathrm{mg}, 78 \%$ (as the TFA salt). Some of 1a-TFA salt was converted into the free base for characterization purposes by washing its' $\mathrm{CH}_{2} \mathrm{Cl}_{2}$ solution with saturated $\mathrm{NaHCO}_{3}$. The spectroscopic properties of $\mathbf{1 a}$ were in agreement with the literature data.

C343-EDA (2a): Yield: $32 \mathrm{mg}, 62 \%$. Some of 2a-TFA salt was converted into the free base and characterised. ${ }^{1} \mathrm{H}$ NMR $\left(\mathrm{DMSO}_{6}, \delta\right): 9.00(\mathrm{~m}, 1 \mathrm{H}), 8.58(\mathrm{~s}, 1 \mathrm{H}), 6.99(\mathrm{~s}, 1 \mathrm{H}), 3.50(\mathrm{q}, \mathrm{J}=6.0$ 
$\mathrm{Hz}, 2 \mathrm{H}), 3.31(\mathrm{q}, \mathrm{J}=6.0 \mathrm{~Hz}, 4 \mathrm{H}), 2.91(\mathrm{t}, \mathrm{J}=6.0 \mathrm{~Hz}, 2 \mathrm{H}), 2.87$ (t, J = 6.0 Hz, 2H), $2.76(\mathrm{t}, \mathrm{J}=6.0 \mathrm{~Hz}$, 2H), $1.96(\mathrm{~m}, 4 \mathrm{H}), 1.67$ (br s, $3 \mathrm{H}$, overlapping with $\mathrm{H}_{2} \mathrm{O}$ signal); ${ }^{13} \mathrm{C}$ NMR (DMSO- $d_{6}, \delta$ ): 164.3, $163.3,152.9,148.4,148.3,127.2$, 119.8, 109.2, 108.4, 105.9, 50.4, 50.0, 42.9, 42.1, 27.7, 21.3, 20.4, 20.3 .

Pt porphyrin-(EDA-coumarin) $)_{4}$ adducts 3 and 4 (general procedure). PtTCPP (20 mg, 0.020 mmol) and CDMT (14 mg, 0.0784) were dissolved in DMF (10 ml). NMM (9 $\mu \mathrm{L}, 0.080 \mathrm{mmol})$ was added to the mixture at $0^{\circ} \mathrm{C}$. The resulting mixture was stirred for $2 \mathrm{~h}$ at $0^{\circ} \mathrm{C}$, and a solution of EDAcoumarin $(0.088 \mathrm{mmol})$ and NMM $(10 \mu \mathrm{L}, 0.088 \mathrm{mmol})$ in DMF $(10 \mathrm{ml})$ was added. The mixture was stirred for another $2 \mathrm{~h}$ at $0^{\circ} \mathrm{C}$ and then overnight at r.t. The solvent was evaporated, and the residue was washed successively with water, $10 \%$ citric acid, water, saturated $\mathrm{NaHCO}_{3}$ and water again. The solid was dried in vacuum and dissolved in a minimal amount of DMF. The resulting concentrated solution was diluted with ether until no more solid precipitated out of the solution. The precipitate was isolated and dried under vacuum to afford the desired compound.

Pt porphyrin-(EDA-CCA) 4 (3). 3 was isolated as an orange, powdery solid. Yield: $20 \mathrm{mg}, 54$ \%. ${ }^{1} \mathrm{H}$ NMR $\left(\mathrm{DMSO}_{6}, \delta\right): 9.05-8.95(\mathrm{~m}, 4 \mathrm{H}), 8.93(\mathrm{~s}, 4 \mathrm{H}), 8.73(\mathrm{~s}, 8 \mathrm{H}), 8.26(\mathrm{~m}, 16 \mathrm{H}), 7.99(\mathrm{~d}, J=$ $8 \mathrm{~Hz}, 4 \mathrm{H}), 7.73(\mathrm{t}, J=8 \mathrm{~Hz}, 4 \mathrm{H}), 7.49(\mathrm{~d}, J=8 \mathrm{~Hz}, 4 \mathrm{H}), 7.42$ (t, $J=8 \mathrm{~Hz}, 4 \mathrm{H}), 4.34$ (t, $J=5 \mathrm{~Hz}, 4 \mathrm{H})$, 3.70-3.60 (m, 16H); UV-Vis (DMF) $\lambda_{\max }(\log \varepsilon): 300$ (4.63), 403 (5.28), 510 (4.39), 540 (3.68), 569 (2.67); MALDI-TOF $(\mathrm{m} / \mathrm{z})$ : calcd for $\mathrm{C}_{96} \mathrm{H}_{68} \mathrm{~N}_{12} \mathrm{O}_{16} \mathrm{Pt}: 1839.45$, found: $1839.32\left[\mathrm{M}^{+}\right]$.

Pt porphyrin-(EDA-C343) 4 (4). 4 was obtained as a dark red solid after precipitation from DMF by Et $\mathrm{E}_{2} \mathrm{O}$. Yield: $20 \mathrm{mg}, 61 \%$. ${ }^{1} \mathrm{H}$ NMR (Pyridine- $\left.d_{5}, \delta\right): 9.77$ (s, 8H), 9.10-8.85 (m, 16H), 8.90$8.75(\mathrm{~m}, 4 \mathrm{H}), 8.32(\mathrm{~s}, 4 \mathrm{H}), 6.91(\mathrm{~s}, 4 \mathrm{H}), 4.18(\mathrm{~m}, 16 \mathrm{H}), 3.10-2.95(\mathrm{~m}, 16 \mathrm{H}), 2.60-2.70(\mathrm{~m}, 8 \mathrm{H}), 2.55-$ $2.45(\mathrm{~m}, 8 \mathrm{H}), 1.70-1.55(\mathrm{~m}, 16 \mathrm{H})$; UV-Vis (DMF) $\lambda_{\max }(\log \varepsilon): 403$ (5.40), 510 (4.43), 540 (3.78), 585 (3.39); MALDI-TOF (m/z): calcd for $\mathrm{C}_{120} \mathrm{H}_{104} \mathrm{~N}_{16} \mathrm{O}_{16} \mathrm{Pt}: 2219.75$, found: 2222.22 [M ${ }^{+}$].

Pt porphyrin-(EDA-C343) $)_{8}$ (5). PtOCPP (10 mg, $\left.0.0086 \mathrm{mmol}\right)$ was dissolved in DMF (10 ml) and activated by CDMT (18 mg, $0.0086 \mathrm{mmol})$ and NMM $(11 \mu \mathrm{L}, 0.103 \mathrm{mmol})$ at $0^{\circ} \mathrm{C}$ during $12 \mathrm{~h}$. A mixture of 4 (taken as a TFA-salt) $(34 \mathrm{mg}, 0.103 \mathrm{mmol})$ and NMM (13 $\mu 1,0.113 \mathrm{mmol})$ was added and the resulting mixture was stirred for $2 \mathrm{~h}$ at $0^{\circ} \mathrm{C}$ and then for 2 days at r.t. After aqueous workup and precipitation from DMF-ether, the precipitated was washed with THF and dried in vacuum, giving pure 5 as a red-orange powder. Yield: $23 \mathrm{mg}, 74 \%$. ${ }^{1} \mathrm{H}$ NMR (DMSO- $d_{6}, \delta$ ): 9.10-8.4 (overlapping peaks, $16 \mathrm{H}+8 \mathrm{H}+8 \mathrm{H}+4 \mathrm{H}), 8.20(\mathrm{~s}, 8 \mathrm{H}), 6.71(\mathrm{~s}, 4 \mathrm{H}), 3.80-3.20(\mathrm{~m}, 32 \mathrm{H}), 3.20-2.80(\mathrm{~m}, 32 \mathrm{H}), 1.90-$ 1.40 (m, 32H); UV-Vis (DMF) $\lambda_{\max }(\log \varepsilon): 403$ (5.32), 510 (4.19), 540 (3.76), 585 (3.27); MALDITOF (m/z): calcd for $\mathrm{C}_{120} \mathrm{H}_{104} \mathrm{~N}_{16} \mathrm{O}_{16} \mathrm{Pt}$ : 3634.77, found: broad 1833-4100 [ $\left.\mathrm{M}^{+}\right]$ 
Table 1. ${ }^{1} \mathrm{H}$ NMR resonances of C343-fragments in Coumarin-343, 4 and $5\left(\mathrm{DMSO}_{\mathrm{d}}, 21^{\circ} \mathrm{C}\right)$

\begin{tabular}{llllll}
\hline Compound & Vinylic $\mathrm{H}$ & Aromatic $\mathrm{H}$ & Aliphatic $\mathrm{H}$ & Aliphatic $\mathrm{H}$ & Aliphatic H \\
\hline Coumarin-343 & 8.44 & 7.23 & 3.34 & 2.71 & 1.87 \\
$\mathbf{4}$ & 8.50 & 7.16 & 3.33 & 2.65 & 1.80 \\
$\mathbf{5}$ & 8.20 & 6.70 & 3.13 & Overlapped & 1.69 \\
& & & \multicolumn{3}{c}{ with solv. } \\
\hline
\end{tabular}

Pt porphyrin-(lys $\left.(\mathbf{C B z})\left(\mathrm{O}^{t} \mathbf{B u}\right)\right)_{4}$ (6). To a stirred solution of PtTCPP (200 mg, $\left.0.203 \mathrm{mmol}\right)$ and CDMT (291 mg, $1.62 \mathrm{mmol})$ in DMF (30 ml) at $0^{\circ} \mathrm{C}$ NMM (164.2 $\left.\mathrm{mg}, 1.62 \mathrm{mmol}\right)$ was added in one portion. The mixture was stirred for $2 \mathrm{~h}$ at $0^{\circ} \mathrm{C}$, and a solution of lys $(\mathrm{CBz})\left(\mathrm{O}{ }^{t} \mathrm{Bu}\right) \cdot \mathrm{HCl}$ salt $(454$ $\mathrm{mg}, 1.22 \mathrm{mmol})$ and NMM (123.2 $\mathrm{mg}, 1.22 \mathrm{mmol})$ in DMF $(30 \mathrm{ml})$ was added to it. The resulting mixture was stirred for another $2 \mathrm{~h}$ at $0^{\circ} \mathrm{C}$ and then for $12 \mathrm{~h}$ at r.t. The solvent was evaporated in vacuum, and the residue was dissolved in $\mathrm{CH}_{2} \mathrm{Cl}_{2}$. The solution was washed with water, $10 \%$ aqueous citric acid and water and dried over $\mathrm{Na}_{2} \mathrm{SO}_{4}$ anhydr. The solvent was removed by rotary evaporation, and the residue was purified by column chromatography (Selecto silicagel; 20:1, 10:1, and 5:1 $\mathrm{CH}_{2} \mathrm{Cl}_{2} / \mathrm{THF}$ ). The first orange fraction was collected. Evaporation of the solvent and subsequent precipitation of the residue from $\mathrm{CH}_{2} \mathrm{Cl}_{2} / \mathrm{Et}_{2} \mathrm{O}$, followed by drying in vacuum, afforded pure 6 as an orange powder. Yield: $370 \mathrm{mg}, 81 \% .{ }^{1} \mathrm{H} \mathrm{NMR}\left(\mathrm{CDCl}_{3}, \delta\right): 8.68(\mathrm{~s}, 8 \mathrm{H}), 8.25-8.15(\mathrm{~m}, 16 \mathrm{H}), 7.33(\mathrm{~d}$, $J=7.5 \mathrm{~Hz}, 8 \mathrm{H}), 7.30-7.24$ (m, 8H) 7.22-7.17 (m, 4H), 7.14 (d, $J=7.5 \mathrm{~Hz}, 4 \mathrm{H}), 5.10$ (s, 8H), 4.96-4.90 $(\mathrm{m}, 4 \mathrm{H}), 3.33-3.25(\mathrm{~m}, 8 \mathrm{H}), 2.15-2.05(\mathrm{~m}, 4 \mathrm{H}), 2.0-1.97(\mathrm{~m}, 4 \mathrm{H}), 1.75-1.50(\mathrm{~m}+\mathrm{s}, 16 \mathrm{H}+36 \mathrm{H}) ;{ }^{13} \mathrm{C}$ NMR $\left(\mathrm{CDCl}_{3}, \delta\right): 172.2,167.3,156.8,144.9,140.8,136.8,134.2,134.0,131.1,128.7,128.3,126.0$, 121.8, 82.8, 66.9, 53.3, 40.9, 32.8, 29.8, 28.4, 22.7; MALDI-TOF $(\mathrm{m} / \mathrm{z})$ : calcd for $\mathrm{C}_{120} \mathrm{H}_{133} \mathrm{~N}_{12} \mathrm{O}_{20} \mathrm{Pt}$ : 2256.94, found: $2257.41\left[\mathrm{MH}^{+}\right]$.

Pt porphyrin-(lys $\left.\left(\mathbf{O}^{t} \mathbf{B u}\right)\right)_{4}(\mathbf{6 a})$ To a solution of $6(350 \mathrm{mg}, 0.155 \mathrm{mmol})$ in THF (60 ml) $10 \%$ $\mathrm{Pd} / \mathrm{C}$ (350 mg) was added, and the mixture was stirred at r.t. under $\mathrm{H}_{2}$ atm. for $12 \mathrm{~h}$. The resulting reaction mixture was filtered through Celite 545. The solvent was evaporated, the residue was dissolved in a minimal amount of $\mathrm{MeOH}$ and subsequently precipitated by addition of ether to give the pure product. This compound should be stored in the dark and under inert atmosphere. Yield: 176 mg, 65.9\%. ${ }^{1} \mathrm{H}$ NMR (DMSO- $\left.d_{6}, \delta\right): 8.95(\mathrm{~d}, J=8 \mathrm{~Hz}, 4 \mathrm{H}), 8.78(\mathrm{~s}, 8 \mathrm{H}), 8.31$ (dd, $J=8.5 \mathrm{~Hz}$ and 7.5 $\mathrm{Hz}, 16 \mathrm{H}), 4.46(\mathrm{dd}, J=7.5 \mathrm{~Hz}$ and $15.0 \mathrm{~Hz}), 3.50-3.05(\mathrm{~m}, 8 \mathrm{H}), 2.59(\mathrm{t}, J=7 \mathrm{~Hz}, 8 \mathrm{H}), 1.95-1.80(\mathrm{~m}$, $8 \mathrm{H}), 1.52-1.40(\mathrm{~s}+\mathrm{m}, 36 \mathrm{H}+16 \mathrm{H}) ;{ }^{13} \mathrm{C} \mathrm{NMR}\left(\mathrm{DMSO}-d_{6}, \delta\right): 171.7,166.6,143.1,139.9,133.8,133.4$, 
126.3, 121.8, 80.5, 53.6, 41.4, 32.9, 30.5, 27.7, 23.3; MALDI-TOF $(\mathrm{m} / \mathrm{z})$ : calcd for $\mathrm{C}_{88} \mathrm{H}_{108} \mathrm{~N}_{12} \mathrm{O}_{12} \mathrm{Pt}$ : 1719.79, found: $1719.17\left[\mathrm{M}^{+}\right]$.

Pt porphyrin-(lys $\left.\left(\mathbf{O}^{t} \mathbf{B u}\right)-\mathbf{C 3 4 3}\right)_{4}$ (7). C343 (145.4 mg, $\left.0.51 \mathrm{mmol}\right)$ was activated with CDMT (91.3 mg, $0.51 \mathrm{mmol})$ and NMM (52 mg, $0.511 \mathrm{mmol})$ in DMF $(30 \mathrm{ml})$ at $0^{\circ} \mathrm{C}$ during $2 \mathrm{~h}$. 6a $(199.3$ $\mathrm{mg}, 0.12 \mathrm{mmol})$ and NMM (13 $\mu \mathrm{L}, 0.12 \mathrm{mmol})$ in DMF $(30 \mathrm{ml})$ were added to the mixture, and it was was left to react overnight at r.t. After aqueous workup, the product was purified by precipitation from $\mathrm{CH}_{2} \mathrm{Cl}_{2}-\mathrm{MeOH}$ and then from $\mathrm{CH}_{2} \mathrm{Cl}_{2}-\mathrm{Et}_{2} \mathrm{O}$ to give an orange powder. Yield: $221 \mathrm{mg}, 68 \%$. ${ }^{1} \mathrm{H}$ NMR $\left(\mathrm{CDCl}_{3}, \delta\right): 8.96(\mathrm{t}, J=6 \mathrm{~Hz}, 4 \mathrm{H}), 8.74(\mathrm{~s}, 8 \mathrm{H}), 8.56(\mathrm{~s}, 4 \mathrm{H}), 8.30-8.10(\mathrm{dd}, \mathrm{J}=7.5 \mathrm{~Hz}$ and 50 $\mathrm{Hz}, 16 \mathrm{H}), 7.33$ (d, J = $8 \mathrm{~Hz}, 4 \mathrm{H}), 6.70(\mathrm{~s}, 4 \mathrm{H}), 4.85-4.75(\mathrm{~m}, 4 \mathrm{H}), 3.60-3.42(\mathrm{~m}, 8 \mathrm{H}), 2.95-2.70$ (m, $16 \mathrm{H}), 2.63(\mathrm{t}, \mathrm{J}=6.5 \mathrm{~Hz}, 8 \mathrm{H}), 2.16-1.4(\mathrm{~m}+\mathrm{s}, 40 \mathrm{H}+36 \mathrm{H}), 1.35-1.15(\mathrm{~m}, 8 \mathrm{H}) ;{ }^{13} \mathrm{C} \mathrm{NMR}\left(\mathrm{CDCl}_{3}, \delta\right)$ : $172.0,167.4,164.2,163.3,152.7,148.1,148.0,144.4,140.8,134.3,134.12,131.2,126.9,126.3$, 121.9, 119.6, 109.1, 108.3, 105.6, 82.4, 53.7, 49.9, 49.6, 38.8, 31.9, 29.8, 28.3, 26.9, 22.6, 20.7, 20.1; UV-Vis $\left(\mathrm{CH}_{2} \mathrm{Cl}_{2}\right) \lambda_{\max }(\log \varepsilon): 403$ (5.46), 510 (4.43), 540 (3.73), 590 (2.61) nm; MALDI-TOF $(\mathrm{m} / z$, 2,5-dihydroxybenzoic acid): calcd for $\mathrm{C}_{152} \mathrm{H}_{160} \mathrm{~N}_{16} \mathrm{O}_{24} \mathrm{Pt}$ : 2788.14 , found: 2790.13 [M $\left.{ }^{+}\right]$.

Pt porphyrin-(lys(OH)-C343) $\mathbf{4}_{\mathbf{4}} \mathbf{( 8 )}$. To a well-stirred solution of 7 (80 $\left.\mathrm{mg}, 0.029 \mathrm{mmol}\right)$ in $\mathrm{CH}_{2} \mathrm{Cl}_{2}(10 \mathrm{ml})$, TFA $(10 \mathrm{ml})$ was added dropwise at $0^{\circ} \mathrm{C}$ over a period of $15 \mathrm{~min}$. The solution was allowed to react for $1 \mathrm{~h}$, after which the solvent and the excess TFA were evaporated at r.t. in vacuum. The residual TFA was removed by re-dissolving the precipitate in $\mathrm{CH}_{2} \mathrm{Cl}_{2}(10 \mathrm{ml})$ and evaporating it in vacuum several times to give 8 as dark red brown crystals. Yield: $72 \mathrm{mg}, 99 \% .{ }^{1} \mathrm{H}$ NMR (DMSO- $d_{6}$, $\delta): 12.65(\mathrm{br} \mathrm{s}, 4 \mathrm{H}), 8.95(\mathrm{~s}, 4 \mathrm{H}), 8.75(\mathrm{~s}, 8 \mathrm{H}), 8.40(\mathrm{~s}, 4 \mathrm{H}), 8.40-8.10(\mathrm{~m}, 16 \mathrm{H}), 7.01(\mathrm{~s}, 4 \mathrm{H}), 4.55(\mathrm{~m}$, $4 \mathrm{H}), 2.70(\mathrm{~m}, 16 \mathrm{H}), 2.42-2.20(\mathrm{~m}, 16 \mathrm{H}), 1.97(\mathrm{~m}, 16 \mathrm{H}), 1.78-1.20(\mathrm{~m}, 32 \mathrm{H}) ;{ }^{13} \mathrm{C}$ NMR (DMSO- $\left.d_{6}, \delta\right)$ : $173.8,166.6,162.5,161.8,151.7,147.4,147.3,143.0,139.9,133.9,133.5,126.3,121.7,119.0,107.9$, 107.2, 104.2, 52.7, 49.0, 48.4, 38.5, 30.2, 28.7, 26.3, 23.4, 20.1, 19.1, 18.9; MALDI-TOF (m/z): calcd for $\mathrm{C}_{136} \mathrm{H}_{128} \mathrm{~N}_{16} \mathrm{O}_{24} \mathrm{Pt}$ : 2563.89, found: 2559.99 [M $\mathrm{M}^{+}$.

CBz-protected dendron 11. CBz-protected arylglycine 10 (500 mg, $1.34 \mathrm{mmol})$ was coupled with tert-butyl ester Newkome dendron 9 (1.36 g, $2.70 \mathrm{mmol})$ in DMF using the standard CDMT procedure, described e.g. for the synthesis of 6. 11 was purified by column chromatrography (Selecto silicagel; 3:1, 2:1, and 1:1 $\left.\mathrm{CH}_{2} \mathrm{Cl}_{2} / \mathrm{EtOAc}\right)$. The first fraction from elution with $1: 1 \mathrm{CH}_{2} \mathrm{Cl}_{2} / \mathrm{EtOAc}$ was collected. Evaporation of the solvent rendered the pure dendron. Yield: $1.32 \mathrm{~g}, 72.9 \%$. ${ }^{1} \mathrm{H}$ NMR $\left(\mathrm{CDCl}_{3}, \delta\right): 8.49$ (br s, 1H), $8.05(\mathrm{~s}, 2 \mathrm{H}), 7.91$ (s, 1H), 7.41-7.28 (m, 5H), $6.60(\mathrm{~s}, 2 \mathrm{H}), 5.59$ (br s, 1H), $5.14(\mathrm{~s}, 2 \mathrm{H}), 4.04(\mathrm{~d}, J=4.5 \mathrm{~Hz}, 2 \mathrm{H}), 3.80(\mathrm{~s}, 12 \mathrm{H}), 3.67(\mathrm{t}, J=6.5 \mathrm{~Hz}, 12 \mathrm{H}), 2.45(\mathrm{t}, J=6.5 \mathrm{~Hz}$, 12H), $1.39(\mathrm{~s}, 54 \mathrm{H}) ;{ }^{13} \mathrm{C} \mathrm{NMR}\left(\mathrm{CDCl}_{3}, \delta\right): 170.3,168.2,166.1,156.5,138.9,137.0,135.6,128.3$, 
127.7, 79.7, 68.0, 66.7, 65.5, 60.2, 44.1, 35.7, 27.7; MALDI-TOF $(\mathrm{m} / \mathrm{z})$ : calcd for $\mathrm{C}_{68} \mathrm{H}_{106} \mathrm{~N}_{4} \mathrm{O}_{23} \mathrm{Na}$ : 1369.72, found: $1370.29\left[\mathrm{M}+\mathrm{Na}^{+}\right]$.

Deprotected dendron 11a. CBz-Protected dendron 11 (1.23 g, $0.913 \mathrm{mmol})$ was deprotected under a low pressure of $\mathrm{H}_{2}$ in THF $(100 \mathrm{~mL})$ in the presence of $10 \% \mathrm{Pd} / \mathrm{C}(1.00 \mathrm{~g})$. The crude product was purified by column chromatography (Selecto silicagel; $\mathrm{CH}_{2} \mathrm{Cl}_{2}, 2: 1 \mathrm{CH}_{2} \mathrm{Cl}_{2} / \mathrm{THF}$, 1:1 $\mathrm{CH}_{2} \mathrm{Cl}_{2}$ /THF, and THF) to give the pure product as a viscous colorless oil. Yield: $550 \mathrm{mg}, 50 \% .{ }^{1} \mathrm{H}$ NMR (DMSO- $\left.d_{6}, \delta\right): 8.10(\mathrm{~s}, 2 \mathrm{H}), 7.62(\mathrm{~s}, 1 \mathrm{H}), 7.29(\mathrm{~s}, 2 \mathrm{H}), 6.85(\mathrm{~s}, 1 \mathrm{H}), 3.67(\mathrm{~s}, 12 \mathrm{H}), 3.58(\mathrm{t}, \mathrm{J}=$ $6.3 \mathrm{~Hz}, 12 \mathrm{H}$ ), $3.26(\mathrm{~s}, 2 \mathrm{H}), 2.40(\mathrm{t}, \mathrm{J}=6.0,12 \mathrm{H}), 1.35(\mathrm{~s}, 54 \mathrm{H}) ;{ }^{13} \mathrm{C}$ NMR (DMSO- $\left.d_{6}, \delta\right)$ 172.3, 170.2, 166.1, 139.1, 138.8, 135.6, 128.0, 79.7, 68.0, 66.7, 60.2, 45.5, 35.7, 28.0: MALDI-TOF $(\mathrm{m} / \mathrm{z})$ : calcd for $\mathrm{C}_{60} \mathrm{H}_{100} \mathrm{~N}_{4} \mathrm{O}_{21} \mathrm{Na}: 1235.68$, found: $1235.53\left[\mathrm{M}+\mathrm{Na}^{+}\right]$.

Pt porphyrin-dendrimer 12. To a vigorously stirred solution of $8(50 \mathrm{mg}, 0.019 \mathrm{mmol})$ in DMF (10 ml) CDI (13.9 mg, $0.086 \mathrm{mmol})$ was added at r.t. After $1 \mathrm{~h}$ of activation, dendron 11a $(103.9 \mathrm{mg}, 0.086 \mathrm{mmol})$ in DMF $(10 \mathrm{ml})$ was added to the mixture, and it was left to react for 2 days. The solvent was removed by rotary evaporation in vacuum. The residue was dissolved in $\mathrm{CH}_{2} \mathrm{Cl}_{2}$, the solution was washed twice with water and dried over $\mathrm{Na}_{2} \mathrm{SO}_{4}$. After the removal of the solvent by rotary evaporation, the crude product was re-dissolved in THF and purified by size-exclusion column chromatography (Bio-Rad S-X1 Beads, 200-400 mesh, THF). The first colored fraction was collected. Evaporation of the solvent gave a dark orange-brown solid, which was re-crystallized from $\mathrm{CH}_{2} \mathrm{Cl}_{2}$ ether. Yield: $52 \mathrm{mg}, 37 \%$. ${ }^{1} \mathrm{H}$ NMR (DMSO- $d_{6}, 120^{\circ} \mathrm{C}, \delta$ ): 9.79 (br s, $4 \mathrm{H}$ ), 8.90-8.10 (overlapping signals, $8 \mathrm{H}+4 \mathrm{H}+4 \mathrm{H}+8 \mathrm{H}+16 \mathrm{H}), 7.64(\mathrm{~s}, 4 \mathrm{H}), 7.10-6.85$ (overlapping signals, $4 \mathrm{H}+8 \mathrm{H}), 4.70-4.50(\mathrm{~m}$, $4 \mathrm{H}$ ), 4.10-3.95 (m, 8H), 3.80-3.50 (overlapping signals, $48 \mathrm{H}+48 \mathrm{H}$ ), 3.16 (br s, $8 \mathrm{H}$ ), 3.00-2.55 (overlapping multiplets, $32 \mathrm{H}$ ), 2.50-2.20 (overlapping multiplets, $48 \mathrm{H}$ ), 2.10-1.45 (overlapping multiplets, $40 \mathrm{H}), 1.42-1.20$ (m, 216). Using analytical SEC, the compound was found to be pure (one peak) with a number average molecular weight $\left(M_{n}\right)$ of 7096 and polydispersity $\left(M_{w} / M_{n}\right)$ of 1.204. The molecular weight of the compound could not be verified by MS. Only peak fragmentations were observed between 3,000 and 8,000 Dalton. However, using DHBA as a matrix and NaI as an additive, we were able to obtain a satisfactory MALDI spectrum of the dendrimer $\mathbf{1 3}$ (see below), synthesized from 12 by hydrolysis of $t \mathrm{Bu}$ groups. UV-Vis $\left(\mathrm{CH}_{2} \mathrm{Cl}_{2}\right) \lambda_{\max }(\log \varepsilon)$ : 403 (5.59), 510 (4.61), 540 (3.95), 590 (3.18).

Water soluble Pt porphyrin-dendrimer 13. Hydrolysis of the ${ }^{t} \mathrm{Bu}$ ester groups in $\mathbf{1 2}$ followed the procedure described for the preparation of $\mathbf{8} . \mathbf{1 3}$ was isolated as a dark brown shiny solid. Yield: $16 \mathrm{mg}, 70 \%$. ${ }^{1} \mathrm{H}$ NMR (DMSO- $d_{6}, \delta$ ): 12.50-11.60 (br s, 24H), 11.30 (s, 2H), 10.15 (s, 2H), 9.20-8.80 (overlapping signals, $4 \mathrm{H}+8 \mathrm{H}+4 \mathrm{H}+16 \mathrm{H}+8 \mathrm{H}+4 \mathrm{H}), 7.65(\mathrm{~s}, 4 \mathrm{H}), 7.42(\mathrm{~s}, 8 \mathrm{H}), 7.11(\mathrm{~m}, 4 \mathrm{H}), 4.55(\mathrm{~m}$, 
4H), $4.02(\mathrm{~m} \mathrm{4H}), 3.67(\mathrm{~s}, 48 \mathrm{H}), 3.32(\mathrm{~m}, 48 \mathrm{H}), 3.00-2.55$ (overlapping multiplets, 44H), 2.50-2.0 (m, 48H), 2.00-1.50 (overlapping multiplets, $40 \mathrm{H})$; UV-Vis $\left(\mathrm{CH}_{2} \mathrm{Cl}_{2}\right) \lambda_{\max }(\log \varepsilon)$ : 403 (5.49), 510 (4.56), 540 (4.03), 590 (3.59). MALDI-TOF $(\mathrm{m} / \mathrm{z})$ : calcd for $\mathrm{C}_{280} \mathrm{H}_{328} \mathrm{~N}_{32} \mathrm{O}_{104} \mathrm{Pt}$ : 6000.83 , found: broad peak with $\mathrm{M}_{\max }$ at $5997.01\left[\mathrm{M}^{+}\right]$.

\section{References}

1. Vinogradov, S. A.; Lo, L. W.; Wilson, D. F. Chem.- Eur. J. 1999, 5, 1338.

2. Mei, E. W.; Vinogradov, S. A.; Hochstrasser, R. M. J. Am. Chem. Soc. 2003, 125, 13198.

3. Cardona, C. M.; Gawley, R. E. J. Org. Chem. 2002, 67, 1411.

4. Vinogradov, S.A. Organic Lett. 2005, 7, 1761.

5. Seybold, P. G.; Gouterman, M. J. Mol. Spectrosc. 1969, 31, 1.

6. Saltiel, J.; Atwater B. W. in Advances in Photochemistry, Ed.: D. H. Volman, G. S. Hammond, K. Gollnick, Wiley, New York, Vol. 14; pp 1-90, 1988.

7. Vinogradov, S. A.; Fernandez-Seara, M. A.; Dugan, B. W.; Wilson, D. F. Rev. Sci. Instrum. 2001, 72, 3396.

8. Vanderkooi, J. M.; Maniara, G.; Green, T. J.; Wilson, D. F. J. Biol. Chem 1987, 262, 5476.

9. Rozhkov, V. V.; Wilson, D. F.; Vinogradov, S. A. Macromolecules 2002, 35, 1991.

10. Rumi, M.; Ehrlich, J. E.; Heikal, A. A.; Perry, J. W.; Barlow, S.; Hu, Z. Y.; McCord-Maughon, D.; Parker, T. C.; Rockel, H.; Thayumanavan, S.; Marder, S. R.; Beljonne, D.; Bredas, J. L. J. Am. Chem. Soc. 2000, 122, 9500.

11. Xu, C.; Webb, W. W. J. Opt. Soc. Am. B 1996, 13, 481.

12. Roy, B. C.; Peterson, R.; Mallik, A. D.; Campiglia, J. J. Org. Chem. 2000, 65, 3644. 